\title{
PREDIKSI JUMLAH TAMU MENGINAP DI HOTEL KARLITA INTERNATIONAL, TEGAL, JAWA TENGAH
}

\author{
Haryadi Sarjono; Irwan Zulkifli \\ Management Department, School of Business Management, BINUS University \\ Jln. K. H. Syahdan No. 9, Palmerah, Jakarta Barat 11480 \\ haryadisarjono@yahoo.com; izulfikli@binus.edu
}

\begin{abstract}
Article is forecasting comparative analysis of number of guess room occupancy at Karlita International Hotel, Tegal, Central Java using 11 forecasting methods: linear regression, moving average, weighted moving average, exponential smoothing, exponential smoothing with trend, naïve method, trend analysis, additive decomposition - CMA, additive decomposition - average all, multiplicative decomposition - CMA, multiplicative decomposition - average All. Article used 17 data from January 2012 to Mei 2013, and results after using those 11 methods were the smallest MAD is 101.69 and the smallest MSE is 15,163.95. From additive decomposition - average all method, data showed guess room occupancy forecast at Karlita International Hotel for June 2013 is 960 guess.
\end{abstract}

Keywords: forecasting, guess room occupancy, MAD, MSE

\begin{abstract}
ABSTRAK
Penelitian ini bertujuan untuk memprediksi jumlah tamu yang akan menginap di Hotel Karlita International, Tegal, Jawa Tengah, dengan teknik analisis yang digunakan adalah menggunakan pendekatan metode peramalan yang terdiri dari 11 metode yaitu: linear regression, moving average. weighted moving average, exponential smoothing, exponential smoothing with trend, naïve method, trend analysis, additive decomposition - CMA, additive decomposition - average all, multiplicative decomposition - CMA, dan multiplicative decomposition - average All. Data yang digunakan dalam penelitian ini sebanyak 17 data dari periode Januari 2012 sampai Mei 2013. Dari hasil penelitian yang menggunakan 11 metode forecasting tersebut didapat MAD terkecil sebesar 101,69 dan MSE terkecil sebesar 15.163,95. Pada metode additive decomposition - average all menunjukkan bahwa data tersebut memperlihatkan peramalan jumlah tamu yang menginap di Hotel Karlita International untuk periode Juni 2013 sebesar 960 tamu.
\end{abstract}

Kata kunci: Prediksi, jumlah tamu menginap, MAD, MSE. 


\section{PENDAHULUAN}

Sebelum dekade 1980-an, peramalan (forecasting) masih dipandang sebagai kegiatan yang teknis di dunia barat. Sedangkan pada dekade 1990-an, pandangan yang sama juga masih dirasakan di kalangan pebisnis Indonesia dan di negara berkembang lainnya. Padahal di tempat asalnya (Amerika Serikat) cakupan peramalan telah berkembang dengan pesat melampaui sifatnya yang teknis, meliputi penggunaan yang luas dalam perencanaan, pengambilan keputusan, serta ilmu-ilmu manajerial lainnya (Siregar, 1996).

Secara umum, peramalan dapat dikelompokkan ke dalam peramalam kuantitatif dan peramalan kualitatif. Peramalan kualitatif adalah peramalan yang didasarkan pada intuisi dan pengalaman empiris, sehingga relatif bersifat subjektif. Untuk situasi yang kompleks, peramalan subjektif sukar dilaksanakan karena keterbatasan otak manusia dalam menganalisis informasi serta hubungan sebab akibat yang memengaruhi bisnisnya. Jika peramalan kualitatif tersebut dilakukan oleh beberapa orang secara terpisah, hasilnya akan memiliki variasi yang cukup besar. Sebaliknya, jika dilaksanakan secara bersama-sama, kemungkinan tidak diperoleh kesamaan hasil peramalan, atau orang yang berpengaruh pada kelompok yang menentukan hasilnya.

Pada sisi lainnya peramalan kuantitatif memiliki sifat yang objektif karena didasarkan pada keadaan aktual (data) yang diolah dengan metode tertentu. Penggunaan suatu metode juga harus didasarkan pada fenomena manajemen bisnis, perubahan yang diramalkan dan untuk tujuan peramalan itu dilaksanakan. Dengan digunakannya data yang merupakan representasi gambaran keadaan aktual masa lalu serta adanya justifikasi teoretis mengenai metode yang digunakan secara sistematis, maka hasil dari peramalan kuantitatif menjadi sesuatu yang dapat dipertanggungjawabkan karena memiliki dasar yang jelas. Selain itu, dengan perkembangan teknologi komputer yang sedemikian pesat, peramalan kuantitatif akhirnya dipandang sebagai sesuatu kegiatan yang tidak terlalu sukar untuk diterapkan dan dapat memberikan hasil yang akurat.

Hal inilah yang memberikan inspirasi untuk membuat penelitian dengan tema tentang peramalan (forecasting) dengan objek hotel Karlita International, Tegal, Jawa Tengah, tempat penulis bekerja. Hal itu mengingat selama ini hampir tidak pernah dilakukan peramalan (prediksi) secara ilmiah tentang jumlah pengunjung (tamu) yang akan menginap di hotel Karlita sehingga pihak manajemen selalu kesulitan ketika tiba-tiba kedatangan tamu yang di luar perkiraan. Selama ini prediksi hanya mengandalkan data historis saja, berdasarkan pengalaman periode sebelumnya. Gambar 1 berikut menunjukkan jumlah tamu yang menginap di Hotel Karlita, Tegal, selama periode Januari 2012 - Mei 2013.

Number Of Room Sold Year 2012-2013

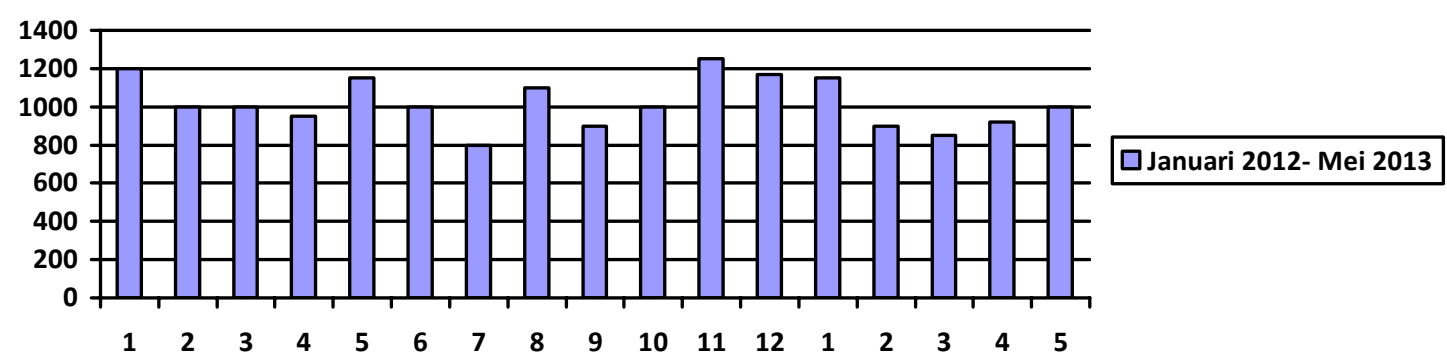

Gambar 1 Jumlah Tamu Menginap selama Periode Januari 2012 - Mei 2013

(Sumber: Hotel Karlita International, Tegal, 2013) 
Ramalan tentang sesuatu yang akan terjadi bisa dilakukan dengan cara teknik perhitungan matematika (ilmiah) maupun dengan cara nonilmiah. Tidak dipungkiri bahwa banyak perusahaan sekarang telah melakukan peramalan produksi dengan teknik perhitungan potensi produksi. Hotel Karlita International yang beralamatkan di Jalan Brigjend Katamso 31, Tegal 52111 (Jawa Tengah), mengalami kesulitan dalam meramalkan jumlah kedatangan tamu hotel yang akan menginap. Akibat kesulitan meramalkan tersebut banyak kesalahan dalam perencanaannya. Oleh karena itu Hotel Karlita International perlu melakukan peramalan terhadap tamu yang menginap pada periode yang akan datang. Selain itu, diperlukan juga persiapan yang lebih baik berhubungan dengan pelayanan terhadap tamu yang akan menginap. Untuk menghadapi masalah prediksi tamu yang akan menginap periode akan datang, dilakukan dengan menggunakan analisis kuantitatif yang bertujuan untuk menentuan budget keuangan perusahaan dan mengefektifkan rencana budget tersebut.

Penelitian ini memanfaatkan data sekunder dengan segala keterbatasannya, sehingga hasil penelitian ini mungkin masih kurang dari yang diharapkan. Adapun batasan-batasan masalahnya sebagai berikut: hanya menghitung prediksi/ramalan jumlah tamu yang akan menginap di Hotel Karlita International, Tegal, Jawa Tengah pada periode Juni 2013 dan penelitian ini dilakukan di hotel Karlita International, Tegal, Jawa Tengah. Berdasarkan kondisi tersebut, rumusan masalah yang dijadikan sebagai bahan penelitian adalah (1) jumlah tamu (pengunjung) yang akan menginap di hotel Karlita International, Tegal, Jawa Tengah, pada periode Juni 2013 dengan menggunakan perhitungan 11 metode secara manual; dan (2) jumlah tamu (pengunjung) yang akan menginap di hotel Karlita International, Tegal, Jawa Tengah, pada periode Juni 2013 dengan menggunakan perhitungan 11 metode QM for windows. Sementara tujuan penelitian adalah sebagai bahan pendukung dan memperkuat teori dari materi yang diuraikan dalam penelitian.

\section{Landasan Teori}

Beberapa ahli mendefinisikan manajemen operasi sebagai berikut. Heizer dan Render (2006) mengatakan bahwa manajemen operasi adalah serangkaian aktivitas yang menghasilkan nilai dalam bentuk barang dan jasa dengan mengubah input menjadi output. Menurut Herjanto (2007), manajemen operasional adalah suatu kegiatan yang berhubungan dengan pembuatan barang, jasa dan kombinasinya, melalui proses transformasi dari sumber daya produksi menjadi keluaran yang diinginkan. Sedangkan menurut menurut Handoko (2002) manajemen operasi merupakan usaha-usaha pengelolaan secara optimal penggunaan sumber daya-sumber daya (atau sering disebut faktor-faktor produksi), tenaga kerja, mesin-mesin, peralatan, bahan mentah dan sebagainya dalam proses transformasi bahan mentah dan tenaga kerja menjadi berbagai produk atau jasa. Jadi dari pendapat tersebut, simpulan dari manajemen operasi adalah kegiatan yang berhubungan dengan penciptaan barang dan jasa melalui adanya pengubahan input menjadi output.

Sementara itu, beberapa ahli mendefinisikan peramalan sebagai berikut. Menurut Heizer dan Render (2009), peramalan adalah seni atau ilmu untuk memperkirakan kejadian di masa depan dan melibatkan pengambilan data historis dan memproyeksikannya ke masa mendatang dengan suatu bentuk model matematis. Menurut Tampubolon (2004), peramalan adalah penggunaan data untuk menguraikan kejadian yang akan datang di dalam menentukan sasaran yang dikehendaki. Sedangkan Herjanto (2004) mendefinisikan peramalan adalah proses suatu variabel (kejadian) di masa datang dengan data variabel yang bersangkutan pada masa sebelumnya. Sementara menurut Nasution (2006), peramalan adalah proses memperkirakan berapa kebutuhan di masa datang yang meliputi kebutuhan dalam urusan kuantitas, kualitas, waktu dan lokasi yang dibutuhkan dalam rangka memenuhi permintaan barang atau jasa.

Heizer dan Render (2009) mengatakan bahwa berbagai organisasi merupakan tiga jenis peramalan yang utama dalam perencanaan operasi pada masa depan. Peramalan Ekonomi (Economic Forecast) menjelaskan siklus bisnis dengan memprediksikan tingkat inflasi, ketersediaan uang, dana 
yang dibutuhkan untuk membangun perumahan, dan indikator perencanaan lainnya. Peramalan Teknologi (Technological Forecast) memerhatikan tingkat kemajuan teknologi yang dapat meluncurkan produk baru yang menarik yang membutuhkan pabrik dan peralatan baru. Peramalan Permintaan (Demand Forecast) adalah proyeksi permintaan untuk produk atau layanan suatu perusahaan. Peramalan ini disebut peramalan penjualan yang mengendalikan produksi, kapasitas, serta sistem penjadwalan dan menjadi input bagi perencanaan keuangan, pemasaran, dan sumber daya manusia.

Menurut Ma'arif dan Tanjung (2005), metode peramalan kuantitatif pada dasarnya dapat dibagi menjadi tiga kelompok utama, yaitu: Metode Time Series (deret berkala), Metode Kausal, dan Metode Pemantauan (monitoring). Adapun taksonomi metode peramalan kuantitatif adalah sebagai berikut.

Tabel 1 Taksonomi Metode Peramalan Kuantitatif

\begin{tabular}{|c|c|c|c|}
\hline $\begin{array}{c}\text { Metode } \\
\text { Peramalan }\end{array}$ & $\begin{array}{l}\text { Spesifikasi } \\
\text { Pokok }\end{array}$ & Metode Utama & Deskripsi Ringkas \\
\hline \multirow{4}{*}{ A. Deret Berkala } & \multirow{4}{*}{$\begin{array}{l}\text { Sejarah akan } \\
\text { berulang dengan } \\
\text { sendirinya, } \\
\text { sehingga } \\
\text { keadaan } \\
\text { mendatang } \\
\text { merupakan } \\
\text { kelanjutan masa } \\
\text { lalu }\end{array}$} & 1. Naif & $\begin{array}{l}\text { Sangat sederhana, misalnya ramalan bulan ini } \\
\text { sama dengan observasi tahun lalu untuk bulan } \\
\text { yang sama ditambah } 10 \%\end{array}$ \\
\hline & & 2. Dekomposisi & $\begin{array}{l}\text { Data deret berkala diuraikan menurut } \\
\text { komponennya, yaitu kecenderungan, musiman, } \\
\text { siklik dan acak. }\end{array}$ \\
\hline & & $\begin{array}{l}\text { 3. Time Series } \\
\text { Sederhana }\end{array}$ & $\begin{array}{l}\text { Ramalan diperoleh dari perataan (smoothing) } \\
\text { nilai-nilai pengamatan masa lampau }\end{array}$ \\
\hline & & $\begin{array}{l}\text { 4. Time Series } \\
\text { Lanjutan }\end{array}$ & $\begin{array}{l}\text { Ramalan diperoleh dari kombinasi nilai-nilai } \\
\text { observasi masa lampau dan atau errornya }\end{array}$ \\
\hline \multirow{4}{*}{ B. Kausal } & \multirow{4}{*}{$\begin{array}{l}\text { Ramalan dapat } \\
\text { dilakukan } \\
\text { dengan } \\
\text { memahami } \\
\text { hubungan sebab } \\
\text { akibat: } \\
\text { bagaimana } \\
\text { variasi faktor- } \\
\text { faktor tertentu } \\
\text { menjelaskan } \\
\text { variasi suatu } \\
\text { peubah }\end{array}$} & $\begin{array}{l}\text { 1. Regresi } \\
\text { Sederhana }\end{array}$ & $\begin{array}{l}\text { Variasi pada suatu peubah yang akan diramalkan } \\
\text { dapat dijelaskan oleh variasi pada suatu peubah } \\
\text { lainnya (peubah penjelas) }\end{array}$ \\
\hline & & 2. Regresi Berganda & $\begin{array}{l}\text { Variasi peubah yang akan diperkirakan dijelaskan } \\
\text { oleh variasi dari beberapa peubah penjelas. }\end{array}$ \\
\hline & & $\begin{array}{l}\text { 3. Model Sistem } \\
\text { Persamaan }\end{array}$ & $\begin{array}{l}\text { Peramalan dilakukan dengan pendekatan system } \\
\text { persamaan simultan. Interdepedensi antar semua } \\
\text { peubah diperhitungkan }\end{array}$ \\
\hline & & $\begin{array}{l}\text { 4. Metode } \\
\text { Multivariate }\end{array}$ & $\begin{array}{l}\text { Pendekatan statistik yang memungkinkan prediksi } \\
\text { melalui analisis multivariate time series. }\end{array}$ \\
\hline C. Monitoring & - & Tracking Signals & $\begin{array}{l}\text { Identifikasi terhadap factor nonrandom sehingga } \\
\text { signal peringatan dapat diketahui }\end{array}$ \\
\hline
\end{tabular}

(Sumber: Ma'arif dan Tanjung, 2005)

Sedangkan menurut Heizer dan Render (2009) ada 11 metode peramalan yang dipakai, antara lain: Linear Regression, Moving Average, Weighted Moving Average, Exponential Smoothing, Exponential Smoothing with Trend, Naïve Method, Trend Analysis, Additive Decomposition - CMA, Additive Decomposition - Average All, Multiplicative Decomposition - CMA, dan Multiplicative Decomposition - Average All. Metode sistem peramalan yang sering digunakan dapat dilihat pada Gambar 2 (Makridarkis dan Wheelwright, 2006). 


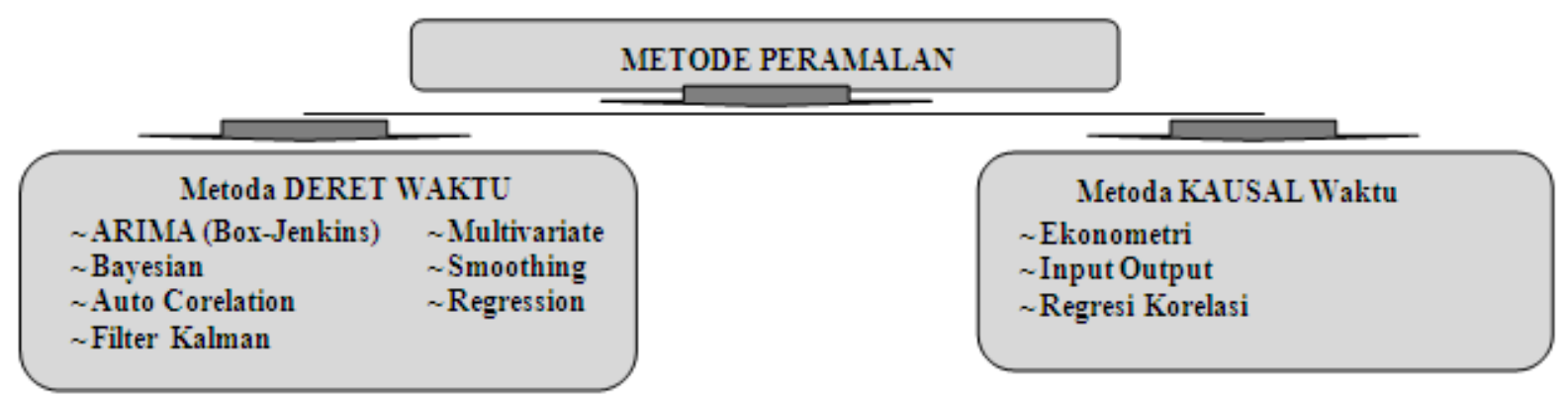

Gambar 2 Metode Sistem Peramalan yang Sering Digunakan

Menurut Render, Stair, dan Hanna (2006) ada tiga model forecasting, yaitu seperti pada Gambar 3 berikut.

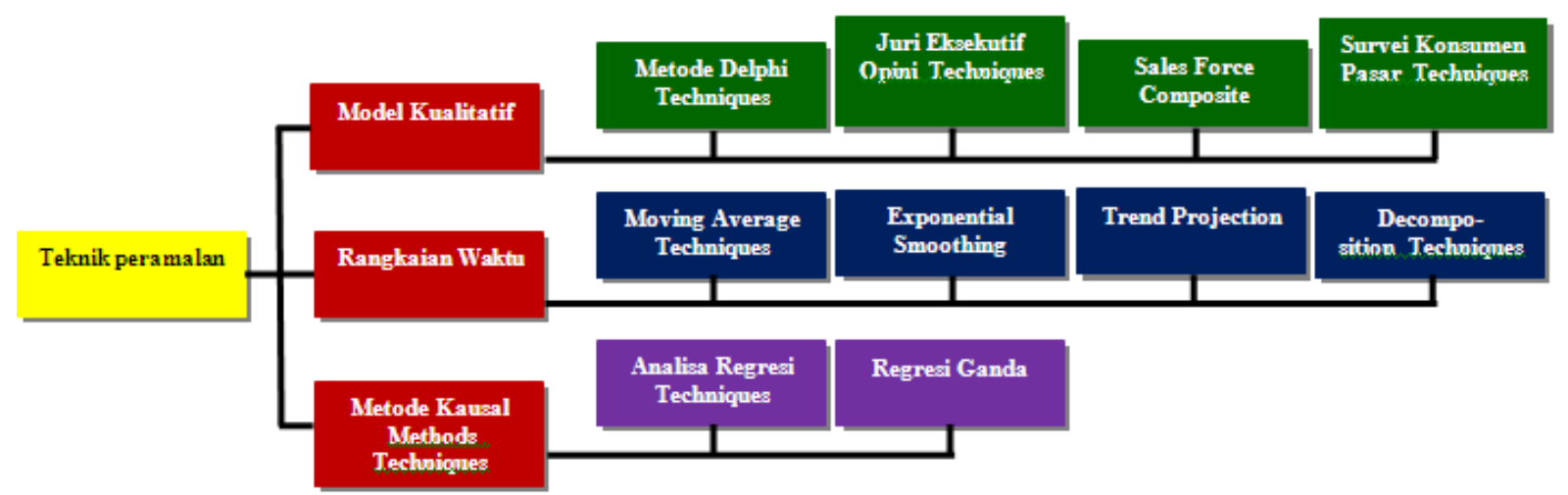

Gambar 3 Pembagian Teknik Peramalan

(Sumber: Render, Stair, dan Hanna, 2006:151)

Menurut Hanke dan Wichern (2007), teknik peramalan mengoperasikan data yang dihasilkan dari peristiwa historis yang menyebabkan identifikasi atas lima langkah proses peramalan berikut ini: perumusan masalah dan koleksi data, manipulasi data dan pembersihan, pembentukan model dan evaluasi, implementasi model (peramalan sebenarnya), dan evaluasi peramalan. Tujuan dari peramalan adalah untuk mengurangi jarak ketidakpastian dalam penilaian manajemen yang harus dibuat. Tujuan ini menyarankan dua aturan utama pada peramalan yang yang harus diikuti (Hanke \& Wichern, 2009), bahwa: peramalan harus benar secara teknis dan peramalan cukup akurat untuk memenuhi kebutuhankebutuhan firma; dan prosedur peramalan dan hasilnya harus secara efektif dipresentasikan kepada manajemen sehingga peramalan digunakan di dalam proses pembuatan keputusan untuk keuntungan firma, hasilnya harus dibenarkan atas dasar biaya-manfaat.

Selain dengan cara manual, analisis peramalan juga dapat dilakukan dengan menggunakan software komputer QM for Windows. QM for Windows merupakan sebuah paket software untuk teknik kuantitatif yang dikembangkan oleh Professor Howard Weiss. Software ini berbasiskan menu dan sangat mudah digunakan bahkan oleh pengguna yang tidak memiliki pengalaman komputer. Fitur yang disediakan $Q M$ for Windows memberikan kemudahan bagi penggunanya (Render, Stair, and Hanna, 2006), antara lain sebagai berikut. (1) Pengguna yang telah mengenal program kertas kerja (spreadsheet) atau pengolah kata (word processing ) di Windows dapat dengan mudah menggunakan $Q M$ for Windows. Semua modul yang ada dapat diakses kapan pun. (2) Walaupun QM for Windows memiliki 19 modul dan 40 submodul, tampilan untuk tiap modul sangat konsisten, sehingga jika pengguna telah terbiasa menggunakan satu modul maka untuk modul berikutnya akan menjadi lebih mudah. (3) Editor dengan jenis kertas kerja memungkinkan untuk melakukan proses editing dengan 
layar penuh. (4) File dibuka dan disimpan sama seperti pada Windows tempat file dinamai sesuai modul yang digunakan sehingga memudahkan jika ingin mencari file yang disimpan sebelumnya.

Beberapa Literature Review yang menggunakan Peramalan (Forecasting) sebagai objek penelitian dan hasil-hasil penelitiannya adalah sebagai berikut. Menurut Rosida (2006) didapat simpulan berikut. (a) Pengujian peramalan dengan perangkat lunak menghasilkan nilai penjualan yang berbeda sebesar $21,08 \%$ dari nilai yang sebenarnya. Peramalan penjualan hanya merupakan salah satu cara untuk memperkirakan kebutuhan persediaan pada periode yang akan datang. Hasil dari peramalan belum tentu tepat karena banyak faktor yang tidak diikutsertakan dalam perhitungannya. (b) Perencanaan pemesanan dengan menggunakan penggabungan rumus frekuensi pemesanan ekonomis dan jumlah pemesanan periodik menghasilkan jumlah pemesanan yang mendekati keadaan sebenarnya. Pengujian menghasilkan $61,54 \%$ data dengan jumlah penjualan sama dengan atau kurang dari jumlah perencanaan pemesanan hasil perhitungan.

Menurut Suhermin (2002) didapat simpulan bahwa dari hasil membandingkan kedua metode, time series regression dan ARIMA pada kasus data jumlah kunjungan wisatawan mancanegara melalui Bandara Ngurah Rai sejak Januari 1998 sampai dengan April 2008, dapat dikatakan bahwa metode peramalan yang terbaik adalah dengan time series regression. Pemilihan metode terbaik ini didasarkan dari kesalahan dugaan/ramalan pada data insample maupun outsample yang ditunjukkan baik oleh nilai MSE maupun nilai MAD. Berdasarkan pengamatan peneliti, hal ini dimungkinkan karena time series regression dapat memungkinkan fleksibilitas dari analisis dengan memilah/memotong seri data berdasarkan pola-pola atau tren tertentu.

Kerangka pemikiran dalam penelitian ini ditunjukkan pada Gambar 3 berikut.

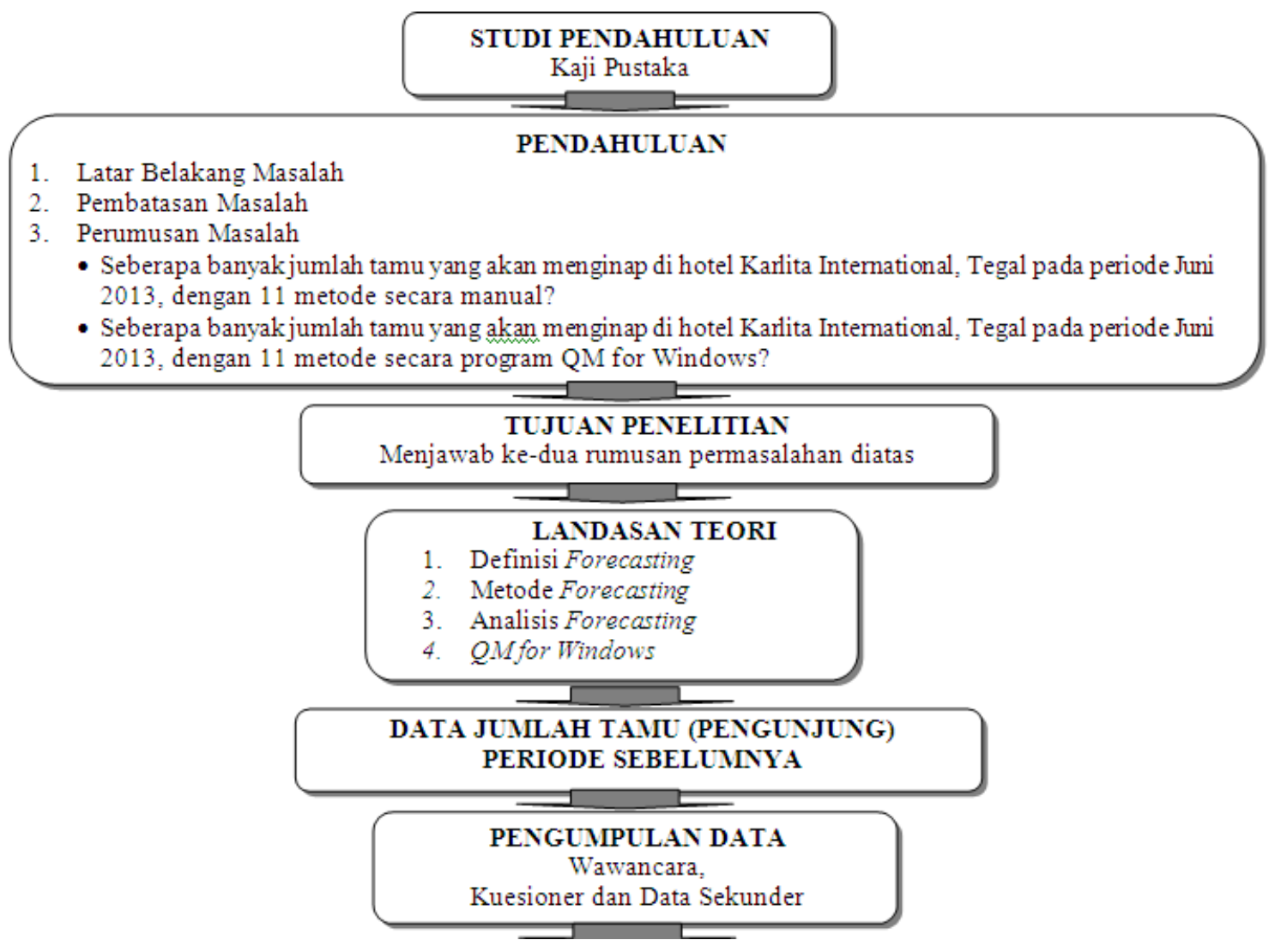




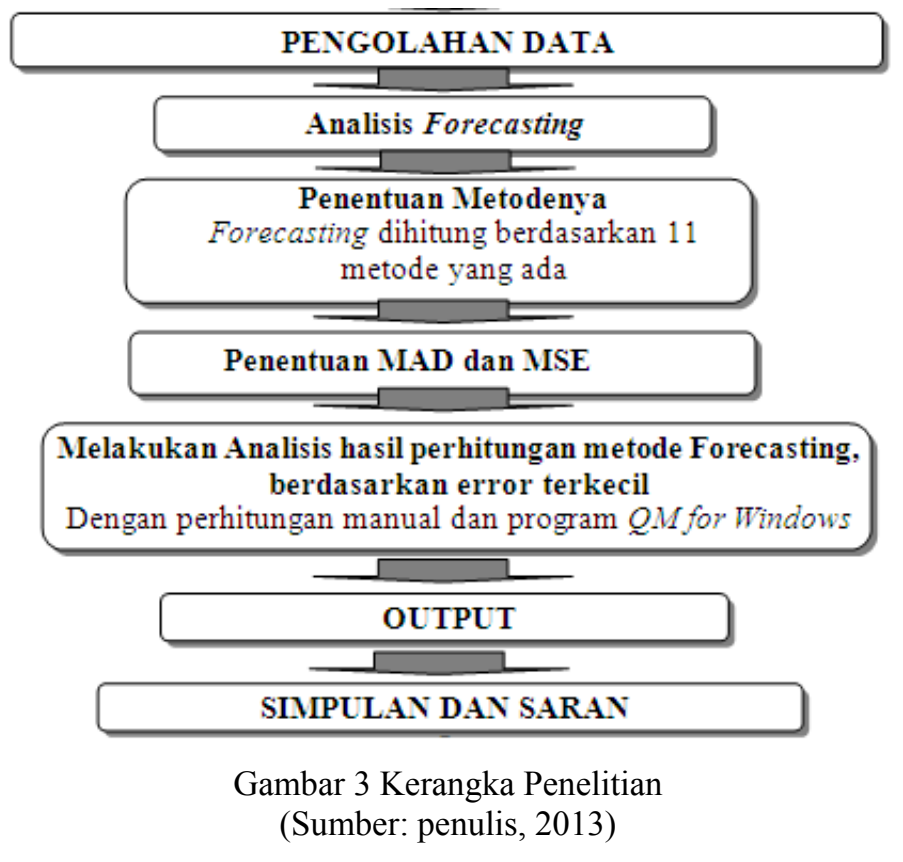

\section{Sejarah Hotel Karlita International}

Semula hotel bernama Hotel Karlita yang terletak di jalan Brigjend Katamso 31, Tegal 52111 (Jawa Tengah), telepon (0283) 358050, berdiri paling awal di kota Tegal sekitar tahun 1976 dan bukan hotel berbintang saat itu. Hingga pada 1996, hotel diambil alih kepemilikan oleh pemilik sekarang, ibu Melinda Feronika dan menjabat sebagai Komisaris Utama. Perkembangan Hotel Karlita saat itu justru terkenal dengan fasilitas utamanya yaitu diskotik dan karaoke, hingga pertengahan 2003 Hotel Karlita dibangun ulang menjadi hotel bertaraf International berbintang tiga plus (mengingat kebijakan pemerintah saat itu untuk membatasi hotel hingga bintang tiga). Fasilitas bertambah menjadi kolam renang di atas gedung lantai 1, Spa dan Aromatherapy Center, 4 jenis kapasitas Function Hall, perluasan Diskotik dan VIP Karaoke, Restoran 24 Jam, penambahan kamar hingga 90 kamar dan fasilitas umum lainnya seperti satu buah Masjid di area parkir dan Gereja Kristen di dalam gedung. Saat itulah nama Hotel Karlita International bertaraf bintang tiga plus dikenal hingga saat ini. Dengan alamat website, www.hotelkarlita.com, Hotel Karlita International saat ini mempunyai jumlah kamar 90 unit yang terdiri dari: Standar Room berjumlah 18 kamar, Deluxe Room 40 kamar, Superior Room 29 Kamar, Suite Room 2 kamar, President Suite 1 kamar. Penambahan gedung saat ini sedang berlangsung untuk memenuhi kebutuhan kamar minimalis modern sebanyak 66 kamar dan diperkirakan selesai pada akhir 2013 sehingga total jumlah kamar yang ada menjadi 155 kamar.
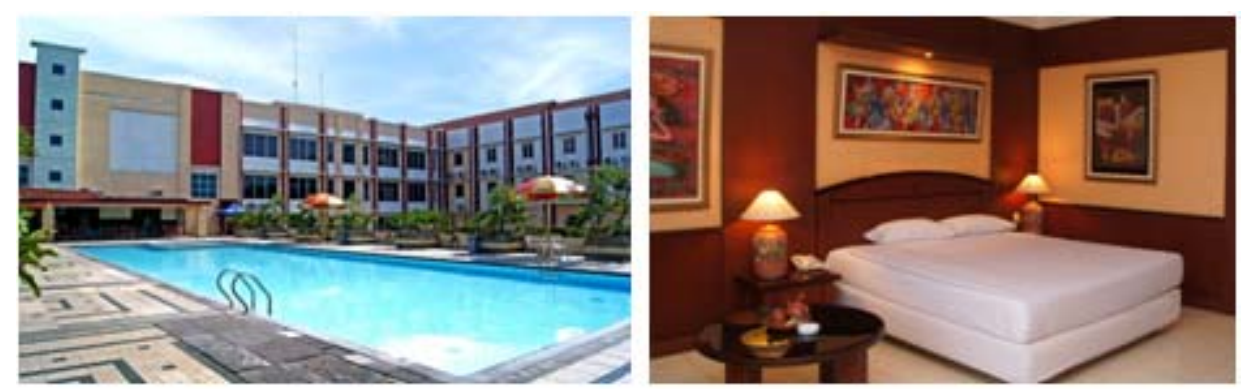

Gambar 4 Hotel Karlita International, Tegal

(Sumber: Hotel Karlita International, Tegal, 2012) 
berikut.

Sedangkan struktur organisasi di Hotel Karlita Internasional, Tegal adalah seperti Gambar 5

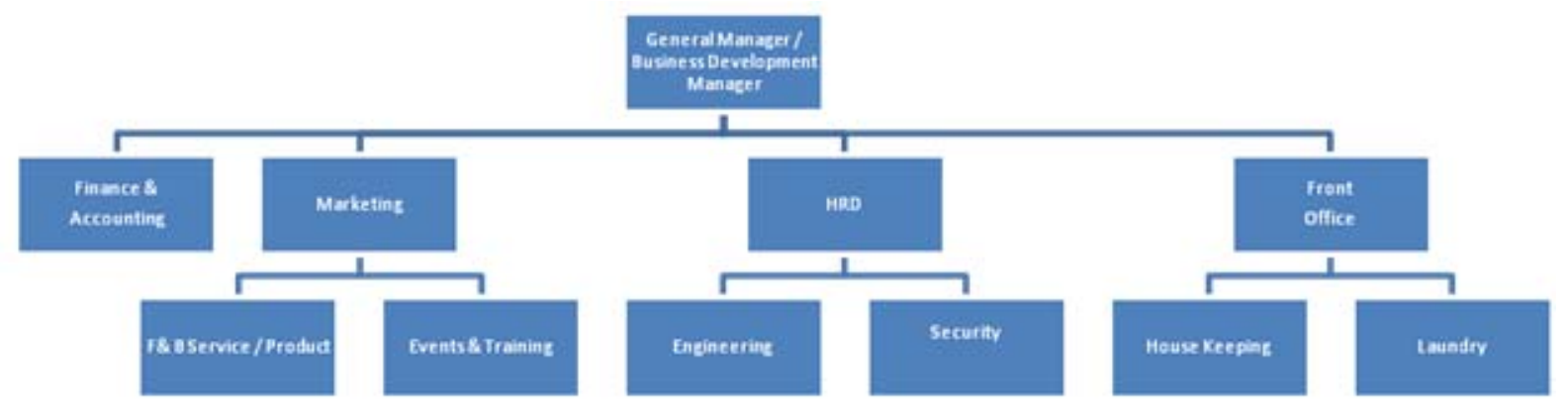

Gambar 5 Struktur Organisasi Hotel Karlita International, Tegal

(Sumber: Hotel Karlita International, Tegal, 2012)

\section{METODE PENELITIAN}

Metode penelitian yang digunakan dalam mengumpulkan data dan informasi adalah dengan: (1) metode deskriptif analisis, yaitu suatu metode yang berusaha memecahkan dan menjawab permasalahan yang sedang dihadapi dengan tujuan untuk menggambarkan secara sistematis aktual dan akurat mengenai fakta-fakta yang diteliti; (2) metode historis analisis, yaitu metode yang digunakan dengan cara mengumpulkan data dan informasi pada masa lampau yang dijadikan pedoman untuk dianalisis pada masa sekarang.

Sumber data dapat dibagi menjadi dua yaitu data internal dan data eksternal. Data internal yaitu data yang didapat dari perusahaan, berupa laporan jumlah kedatanganan tamu per periodik dan informasi internal lainnya. Data eksternal adalah data yang didapat dari luar perusahaan seperti hasil penelitian sebelumnya yang telah dipublikasikan.

Teknik pengumpulan data dilakukan dalam rangka mengumpulkan informasi yang diperlukan dalam penelitian ini dibantu dengan beberapa instrumen, yaitu: Penelitian Lapangan (Field Research); riset yang dilakukan dengan cara melakukan penelitian langsung di objek penelitian, yang berguna untuk memperoleh gambaran umum mengenai keseluruhan. Data yang diperoleh melalui wawancara dan observasi. Penelitian Kepustakaan (Library Research); penelitian ini bertujuan untuk memperoleh data-data sekunder dari perusahaan, surat kabar dan buku yang berkaitan dengan peramalan (forecasting), dilakukan studi kepustakaan melalui buku-buku, artikel, Internet, dan literatur lainnya yang bersifat ilmiah.

Penelitian menggunakan teknik pengambilan sampel secara probability sampling dengan metode sampel acak sederhana (simple random sampling) yang di dalamnya semua anggota populasi mendapatkan kesempatan yang sama untuk terpilih menjadi sampel penelitian. Populasi yang akan diteliti adalah jumlah kedatangan tamu yang menginap di Hotel Karlita International, Tegal pada beberapa periode.

Dalam penelitian ini terdapat dua jenis data yaitu data primer dan data sekunder. Data primer, yaitu data yang diperoleh secara langsung dari simbul data penelitian dilaksanakan. Data primer merupakan informasi yang didapat dari sumber pertama karena melakukan penelitian secara langsung dan bukan merupakan data dari hasil pekerjaan orang lain. Data ini didapat dari penyebaran kuesioner kepada pelanggan dan karyawan, termasuk pula dari hasil wawancara dan observasi untuk 
mendapatkan informasi yang diperlukan dalam penelitian ini. Data sekunder, yaitu data yang diperoleh secara tidak langsung dari objek penelitian melalui literatur yang berhubungan dengan permasalahan yang dibahas. Data sekunder merupakan data yang sudah diolah dalam bentuk laporan, arsip, maupun catatan; data didapatkan dari informasi data perusahaan. Berikut ini gambar yang menunjukkan pengelompokan data.

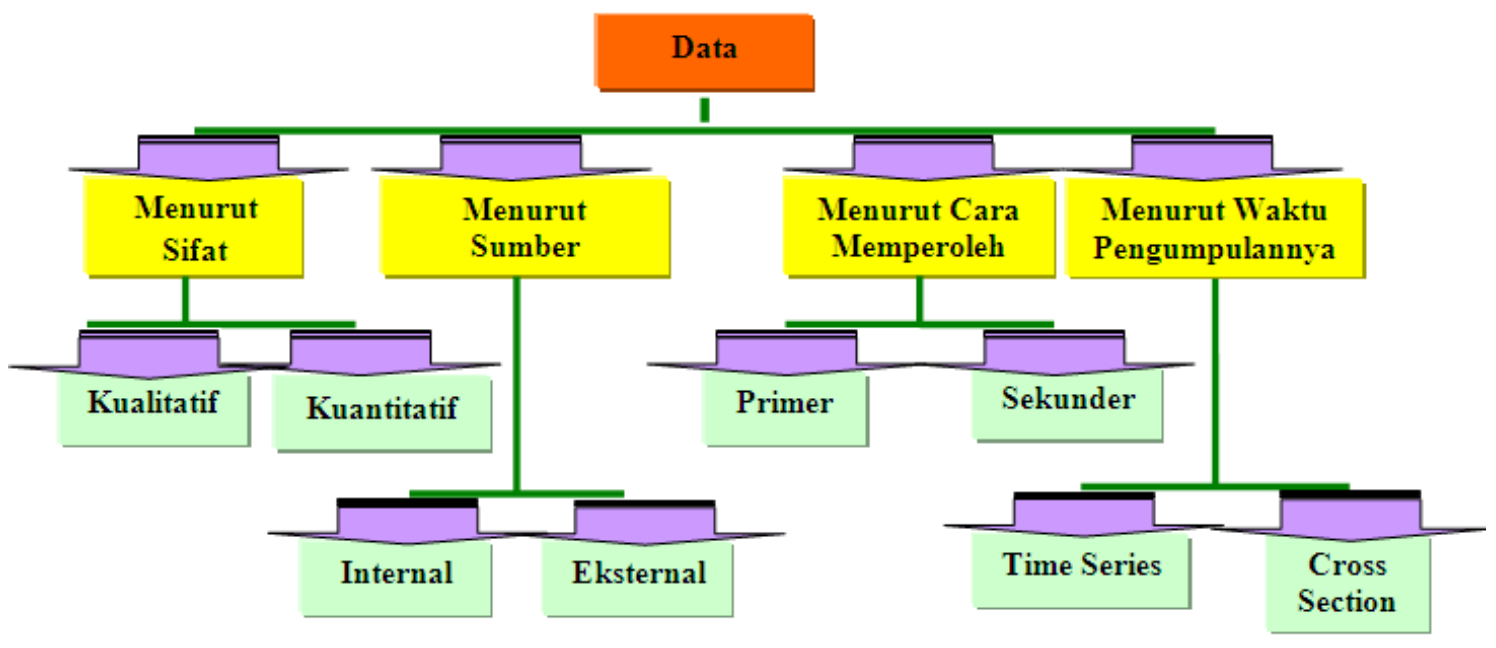

Gambar 5 Pengelompokan Data

(Sumber: Supranto, 2005:10)

Dalam menganalisis proses produksi ini digunakan metode forecasting (peramalan) dengan mengasumsikan permintaan pada setiap periode dari pelanggan. Menurut Render (2009) dalam perhitungan permintaan pelanggan ada 11 metode forecasting (peramalan), yaitu:

\section{Pendekatan Naif (Naive Approach)}

Cara yang paling sederhana untuk meramal adalah berasumsi bahwa permintaan di periode mendatang akan sama dengan permintaan pada periode terakhir.

$$
\mathbf{F}_{\mathbf{t}}=\mathbf{Y}_{\mathrm{t}-1}
$$

\section{Rata-rata Bergerak (Moving Average)}

Peramalan rata-rata bergerak menggunakan sejumlah data aktual masa lalu untuk menghasilkan peramalan. Rata-rata bergerak berguna jika kita dapat mengasumsikan bahwa permintaan pasar akan stabil sepanjang masa yang diramalkan. Secara matematis, rata-rata bergerak sederhana (merupakan prediksi permintaan periode mendatang) dinyatakan sebagai berikut:

$$
\mathbf{F t}=\frac{\sum \text { Permintaan pada periode } \mathbf{n} \text { sebelumnya }}{\mathbf{n}}
$$

dengan $\mathbf{n}$ adalah jumlah periode dalam rata-rata bergerak

\section{Rata-rata Bergerak Tertimbang (Weighted Moving Average)}

Saat terdapat tren atau pola yang terdeteksi, bobot dapat digunakan untuk menempatkan penekanan yang lebih pada nilai terkini. Praktik ini membuat teknik peramalan lebih tanggap terhadap 
perubahan karena periode yang lebih dekat mendapatkan bobot yang lebih berat. Pemilihan bobot merupakan hal yang tidak pasti karena tidak ada rumus untuk menetapkannya. Oleh karena itu, pemutusan bobot yang digunakan membutuhkan pengalaman. Rata-rata bergerak dengan pembobotan atau rata-rata bergerak tertimbang dapat digambarkan secara matematis sebagai berikut:

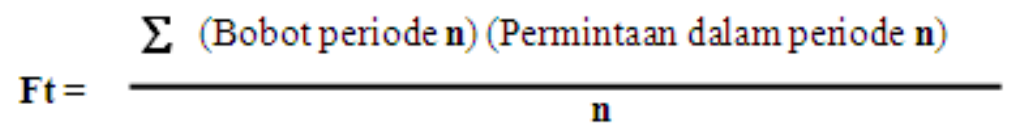

\section{Penghalusan Eksponensial (Exponential Smoothing)}

Penghalusan eksponensial merupakan metode peramalan rata-rata bergerak dengan pembobotan yang canggih tetapi masih mudah digunakan. Metode ini menggunakan pencatatan data masa lalu yang sangat sedikit. Rumus penghalusan eksponensial dasar dapat ditunjukkan sebagai berikut:

$$
\begin{aligned}
& \qquad \mathbf{F}_{\mathbf{t}}=\mathbf{F}_{\mathbf{t}-\mathbf{1}}+\boldsymbol{\alpha}\left(\mathbf{A}_{\mathbf{t}-\mathbf{1}}-\mathbf{F}_{\mathbf{t}-1}\right) \\
& \text { dengan: } \\
& \mathbf{F}_{\mathbf{t}}=\text { peramalan baru } \\
& \mathbf{F}_{\mathbf{t}-\mathbf{1}}=\text { peramalan sebelumnya } \\
& \boldsymbol{\alpha}=\text { konstanta penghalusan (pembobotan) }(0 \leq \alpha \leq 1) \\
& \mathbf{A}_{\mathbf{t}-\mathbf{1}}=\text { permintaan aktual periode lalu }
\end{aligned}
$$

Konstanta penghalusan untuk penerapan di bidang bisnis biasanya berkisar dari 0,05 hingga 0,5. Pendekatan penghalusan eksponensial mudah digunakan dan telah berhasil diterapkan pada hampir setiap jenis bisnis. Walaupun demikian, nilai yang tepat untuk konstanta penghalusan dapat membuat diferensiasi antara peramalan yang akurat dan yang tidak akurat. Nilai $\alpha$ yang tinggi dipilih pada saat rata-rata cenderung berubah. Nilai $\alpha$ yang rendah digunakan saat rata-rata cukup stabil. Tujuan pemilihan suatu nilai untuk konstanta penghalusan adalah mendapatkan peramalan yang akurat.

\section{Penghalusan Eksponensial dengan Tren (Exponential Smoothing with Trend)}

Penghalusan eksponensial yang sederhana gagal memberikan respons terhadap tren yang terjadi. Inilah alasan penghalusan eksponensial harus diubah saat ada tren. Untuk memperbaiki peramalan, maka digunakan model penghalusan eksponensial yang lebih rumit dan dapat menyesuaikan diri pada tren yang ada. Idenya adalah menghitung rata-rata data penghalusan eksponensial, kemudian menyesuaikan untuk kelambatan (lag) positif atau negatif pada tren. Dengan penghalusan eksponensial dengan penyesuaian tren, estimasi rata-rata, dan tren dihaluskan. Prosedur ini membutuhkan dua konstanta penghalusan, $\alpha$ untuk rata-rata dan $\beta$ untuk tren. Kemudian, dihitung rata-rata dan tren untuk setiap periode.

$$
\begin{gathered}
F_{t}=\alpha\left(A_{t-1}\right)+(1-\alpha)\left(F_{t-1}+T_{t-1}\right) \\
T_{t}=\beta\left(F_{t}-F_{t-1}\right)+(1-\beta) T_{t-1}
\end{gathered}
$$

dengan:

$\mathbf{F}_{\mathbf{t}}=$ peramalan dengan eksponensial yang dihaluskan dari data berseri pada periode $\mathrm{t}$

$\mathbf{T}_{\mathbf{t}}=$ tren dengan eksponensial yang dihaluskan pada periode $\mathrm{t}$

$\mathbf{A}_{\mathbf{t}}=$ permintaan aktual pada periode $\mathrm{t}$

$\boldsymbol{\alpha}=$ konstanta penghalusan untuk rata-rata $(0 \leq \alpha \leq 1)$

$\boldsymbol{\beta}=$ konstanta penghalusan untuk tren $(0 \leq \beta \leq 1)$ 
Jadi, tiga langkah menghitung peramalan dengan yang disesuaikan dengan tren adalah sebagai berikut: (a) menghitung $F_{t}$, peramalan eksponensial yang dihaluskan untuk periode $t$, menggunakan persamaan $\mathrm{F}_{\mathrm{t}}$; (b) Menghitung tren yang dihaluskan, $\mathrm{T}_{\mathrm{t}}$, menggunakan persamaan $\mathrm{T}_{\mathrm{t}}$; (c) menghitung peramalan dengan tren, FIT $_{t}$, dengan rumus FIT $_{t}=F_{t}+T_{t}$.

\section{Proyeksi Tren (Trend Projection) atau Analisis Tren (Trend Analysis)}

Teknik ini mencocokkan garis tren pada serangkaian data masa lalu, kemudian memproyeksikan garis pada masa datang untuk peramalan jangka menengah atau jangka panjang.

dengan:

$$
\hat{\mathbf{y}}=\mathbf{a}+\mathbf{b X}
$$

$\hat{\mathbf{y}}=$ nilai terhitung dari variabel yang akan diprediksi (variabel terkait)

$\mathbf{a}=$ persilangan sumbu y

$\mathrm{b}=$ kemiringan garis regresi (tingkat perubahan pada y untuk perubahan yang terjadi di $\mathrm{x}$ )

$\mathbf{x}=$ variabel bebas

$$
\begin{gathered}
\mathbf{b}=\frac{\sum \mathrm{xy}-\mathrm{n}(\bar{x})(\bar{y})}{\sum \mathrm{x}^{2}-\mathrm{n}(\bar{x})^{2}} \\
\bar{y}=\mathbf{a}+\mathbf{b}(\mathrm{x})
\end{gathered}
$$

$\mathbf{x}=$ nilai variabel bebas yang diketahui

$\mathbf{y}=$ nilai variabel terkait yang diketahui

$\overline{\mathbf{X}}=$ rata-rata nilai $\mathrm{x}$

$\overline{\mathbf{Y}}=$ rata-rata nilai y

$\mathbf{n}=$ jumlah data atau pengamatan

\section{Regresi linier (Linear Regression)}

Model matematika garis lurus untuk menggambarkan hubungan fungsional antara variabelvariabel yang bebas maupun variabel terikat. Persamaan garisnya dapat dinyatakan sebagai:

$$
\begin{gathered}
\hat{\mathbf{y}}=\mathbf{a}+\mathbf{b x} \\
\mathbf{b}=\frac{\sum \mathrm{xy}-\mathrm{n}(\bar{x})(\bar{y})}{\sum \mathrm{x}^{2}-\mathrm{n}(\bar{x})^{2}}
\end{gathered}
$$

dengan:

$\hat{\mathbf{y}}=$ nilai terhitung dari variabel yang akan diprediksi (variabel terkait)

$\mathbf{a}=$ persilangan sumbu y

$\mathrm{b}=$ kemiringan garis regresi (tingkat perubahan pada y untuk perubahan yang terjadi di $\mathrm{x}$ )

$\mathbf{x}=$ variabel bebas dimana nilai variabel bebasnya diketahui

$\mathbf{y}=$ nilai variabel terkait yang diketahui

$\overline{\mathrm{X}}=$ rata-rata nilai $\mathrm{x}$

$\overline{\mathrm{Y}}=$ rata-rata nilai $\mathrm{y}$

$\mathbf{n}=$ jumlah data atau pengamatan

\section{Metode Additive Decomposition dan Multiplicative Decomposition}

Metode peramalan additive decomposition terbagi menjadi dua yakni Additive Decomposition - Average All dan Additive Decomposition - Centered Moving Average. Metode peramalan 
multiplicative decomposition juga terbagi menjadi 2 yaitu Multiplicative Decomposition - Average All dan Multiplicative Decomposition - Centered Moving Average.

\section{Additive Decomposition - Average All}

Berikut langkah-langkah perhitungan dalam metode ini: menentukan banyak seasons yang ingin dibagi (misalnya kuartal); menghitung rata-rata penjualan (CTD MA); menghitung difference dengan rumus: penjualan - CTD MA; menghitung nilai seasonal tiap kuartal dengan rumus $\Sigma$ Rasio kuartal ke-i / n dan untuk tiap kuartal yang sama memiliki nilai seasonal yang sama; menghitung nilai smoothed dengan rumus: penjualan - seasonal; kemudian hitung $\mathrm{y}_{\text {uandjusted }}=\mathrm{a}+\mathrm{bx}$ (nilai y yang digunakan adalah y smoothed dan rata-rata penjualan); kemudian dilanjutkan dengan mencari nilai $\mathrm{y}_{\text {adjusted }}=\mathrm{y}_{\text {uandjusted }}+$ seasonal.

\section{Additive Decomposition - Centered Moving Average}

Berikut langkah-langkah perhitungan dalam metode ini: menentukan banyak seasons yang ingin dibagi (misalnya kuartal); menghitung nilai CTD MA; menghitung difference dengan rumus: penjualan - CTD MA; menghitung nilai seasonal tiap kuartal dengan rumus $\Sigma$ Rasio kuartal ke-i / n dan untuk tiap kuartal yang sama memiliki nilai seasonal yang sama; menghitung nilai smoothed dengan rumus: penjualan - seasonal; kemudian menghitung $\mathrm{y}_{\text {uandjusted }}=\mathrm{a}+\mathrm{bx}$ (nilai y yang digunakan adalah y smoothed dan rata-rata penjualan); dan dilanjutkan dengan mencari nilai $\mathrm{y}_{\text {adjusted }}=\mathrm{y}_{\text {uandjusted }}+$ seasonal.

\section{Multiplicative Decomposition - Average All}

Berikut langkah-langkah perhitungan dalam metode ini: menentukan banyak seasons yang ingin dibagi (misalnya kuartal); menghitung rata-rata penjualan (CTD MA); menghitung nilai rasio dengan rumus: penjualan / CMA; menghitung nilai seasonal tiap kuartal dengan rumus $\Sigma$ Rasio kuartal ke-i / n dan untuk tiap kuartal yang sama memiliki nilai seasonal yang sama; menghitung nilai smoothed dengan rumus: penjualan / seasonal; kemudian menghitung $\mathrm{y}_{\text {uandjusted }}=\mathrm{a}+\mathrm{bx}$ (nilai y yang digunakan adalah y smoothed dan rata-rata penjualan); dan dilanjutkan dengan mencari nilai yadjusted $=$ $\mathrm{y}_{\text {uandjusted }}$ * seasonal.

\section{Multiplicative Decomposition - Centered Moving Average}

Berikut langkah-langkah perhitungan dalam metode ini: menentukan banyak seasons yang ingin dibagi (misalnya kuartal); menghitung nilai CTD MA; menghitung nilai rasio dengan rumus: penjualan / CMA; menghitung nilai seasonal tiap kuartal dengan rumus $\Sigma$ Rasio kuartal ke-i / n dan untuk tiap kuartal yang sama memiliki nilai seasonal yang sama; menghitung nilai smoothed dengan rumus: penjualan / seasonal; kemudian menghitung $\mathrm{y}_{\text {uandjusted }}=\mathrm{a}+\mathrm{bx}$ (nilai y yang digunakan adalah $\mathrm{y}$ smoothed dan rata-rata penjualan); dan dilanjutkan dengan mencari nilai $\mathrm{y}_{\text {adjusted }}=\mathrm{y}_{\text {uandjusted }}$ * seasonal.

Menurut Hanke dan Wichern (2007:79-80), ukuran akurasi hasil peramalan ada 2 ukuran yang biasa digunakan, yaitu:

\section{Rata-rata Deviasi Mutlak (Mean Absolute Devitation = MAD)}

MAD merupakan rata-rata kesalahan mutlak selama periode tertentu tanpa memerhatikan jika hasil peramalan lebih besar atau lebih kecil dibandingkan kenyataan. Secara matematis, MAD dirumuskan sebagai berikut: 


$$
\mathbf{M A D}=\Sigma \quad \frac{\mid \text { Aktual }- \text { Hasil Peramalan } \mid \Sigma}{\mathbf{n}} \quad \frac{\mid \text { At }-\mathrm{Ft} \mid}{\mathbf{n}}
$$

dengan:

$$
\begin{aligned}
& \mathbf{A}_{\mathbf{t}}=\text { Permintaan aktual pada periode }-\mathbf{t} \\
& \mathbf{F}_{\mathbf{t}}=\text { Peramalan permintaan (forecast) pada periode }-\mathbf{t} \\
& \mathbf{n}=\text { Jumlah periode peramalan yang terlibat }
\end{aligned}
$$

\section{Rata- rata Kuadrat Kesalahan (Mean square error $=$ MSE)}

MSE yang dihitung dengan menjumlahkan kuadrat semua kesalahan peramalana pada setiap periode dan membaginya dengan jumlah peroide peramalan. Rumus MSE adalah sebagai berikut.

$$
\text { MSE }=\Sigma \frac{(\text { Kesalahan Peramalan })^{2}}{\mathbf{n}}=\Sigma \frac{(\text { At }-\mathrm{Ft})^{2}}{\mathbf{n}}
$$

\section{HASIL DAN PEMBAHASAN}

Peramalan (forecasting) permintaan akan jumlah tamu yang menginap di Hotel Karlita Intenational, Tegal, Jawa Tengah, dihitung dengan cara perhitungan manual dan program QM for Windows dengan menggunakan sebelas metode yang ada, antara lain: Linear Regression, Moving Average, Weighted Moving Average, Exponential Smoothing, Exponential Smoothing with Trend, Naïve Method, Trend Analysis, Additive Decomposition - CMA, Additive Decomposition - Average All, Multiplicative Decomposition - CMA dan Multiplicative Decomposition - Average All.

Data jumlah tamu yang menginap, dimulai dari periode Januari 2012 sampai Mei 2013, adalah sebagai berikut.

Tabel 2 Data Jumlah Tamu yang Menginap di Hotel Karlita International

\begin{tabular}{clc}
\hline No & \multicolumn{1}{c}{ Bulan } & Jumlah Tamu Pengunjung Hotel (Orang) \\
\hline $\mathbf{1}$ & Januari - 2012 & $\mathbf{1 2 0 0}$ \\
2 & Februari & 1000 \\
3 & Maret & 1000 \\
4 & April & 950 \\
5 & Mei & 1150 \\
6 & Juni & 1000 \\
7 & July & 800 \\
8 & Agustus & 1100 \\
9 & September & 900 \\
10 & Oktober & 1000 \\
11 & November & 1250 \\
12 & Desember & 1170 \\
$\mathbf{1 3}$ & Januari - 2013 & $\mathbf{1 1 5 0}$ \\
14 & Februari & 900 \\
15 & Maret & 850 \\
16 & April & 920 \\
17 & Mei & 1000 \\
\hline
\end{tabular}

(Sumber: Hotel Karlita International, Tegal, 2013) 
Sementara Tabel 3 dan Tabel 4 berturut-turut menampilkan hasil perhitungan peramalan secara manual dan hasil perhitungan dengan menggunakan program $Q M$ for Windows untuk 11 metode peramalan.

Tabel 3 Hasil Perhitungan Secara Manual

\begin{tabular}{lrrr}
\hline \multicolumn{1}{c}{ Metode } & \multicolumn{1}{c}{ MAD } & \multicolumn{1}{c}{ MSE } & Forecast (Juni 2013) \\
\hline Linear Regression & 112,196 & $17.101,503$ & 975,8824 \\
Moving Average & 132,1428571 & $24.621,4285$ & 923,3333333 \\
Weighted Moving Average & 127,1428571 & $23.524,4285$ & 946 \\
Exponential Smoothing & 131,9577463 & $22.829,9643$ & 826 \\
Exponential Smoothing with Trend & 151,32059 & $27.807,4928$ & 958,33641 \\
Naïve Method & 137,5 & 26912,5 & 1000 \\
Trend Analysis & 105,836 & $15.364,476$ & 975,891 \\
Additive Decomposition - CMA & 104,096 & $15.235,669$ & 969,8318 \\
Additive Decomposition - Average All & $\mathbf{1 0 1 , 6 9}$ & $\mathbf{1 5 . 1 6 3 , 9 5}$ & $\mathbf{9 6 0 , 8 8 2 1}$ \\
Multiplicative Decomposition - CMA & 105,030 & $15.296,135$ & 973,2616 \\
Multiplicative Decomposition - Average All & 101,504 & $15.157,864$ & 961,85 \\
\hline
\end{tabular}

(Sumber: hasil pengolahan data, 2013)

Tabel 5. Hasil Perhitungan Menggunakan QM For Windows

\begin{tabular}{lrrr}
\hline \multicolumn{1}{c}{ Metode } & \multicolumn{1}{c}{ MAD } & MSE & Forecast (Juni 2013) \\
\hline Linear Regression & 112,6407 & 16635,14 & 975,8824 \\
Moving Average & 98,8096 & 15211,07 & 1010 \\
Weighted Moving Average & 127,1429 & 23524,43 & 946 \\
Exponential Smoothing & 132,0014 & 22864,17 & 977,9882 \\
Exponential Smoothing with Trend & 139,8125 & 25694,71 & 954,7766 \\
Naïve Method & 139,8125 & 25694,71 & 954,7766 \\
Trend Analysis & 105,8362 & 15364,48 & 975,891 \\
Additive Decomposition - CMA & 104,0962 & $15.235,67$ & 969,8318 \\
Additive Decomposition - Average All & $\mathbf{1 0 1 , 5 2 2 5}$ & $\mathbf{1 5 . 1 6 4 , 4 8}$ & $\mathbf{9 6 0 , 8 8 2 1}$ \\
Multiplicative Decomposition - CMA & 105,0303 & $15.296,13$ & 973,2616 \\
Multiplicative Decomposition - Average All & 101,5037 & $15.157,86$ & 961,85 \\
\hline
\end{tabular}

(Sumber: hasil pengolahan data, 2013)

Berdasarkan hasil pengolahan data antara perhitungan secara manual maupun menggunakan QM for Windows dengan 11 metode terhadap jumlah tamu yang menginap di Hotel Karlita International, Tegal, maka jumlah tamu menginap untuk bulan Juni 2013 telah diperoleh hasil MAD dan MSE yang memiliki nilai terkecil relatif sama yaitu 101,69 dan 15.163,95. Pada metode Additive Decomposition - Average All, dihasilkan jumlah forecasting sebesar 960,8821 $\approx 960$ orang tamu yang menginap. Angka tersebut nantinya yang akan dipakai untuk perhitungan selanjutnya.

\section{SIMPULAN}

Berdasarkan analisis dan hasil perhitungan untuk peramalan jumlah tamu yang menginap di Hotel Karlita International, Tegal, Jawa Tengah yang telah diperoleh, dapat disimpulkan antara lain sebagai berikut. Pertama, perhitungan peramalan menggunakan pendekatan 11 metode peramalan, antara lain: linear regression, moving average. weighted moving average, exponential smoothing, exponential smoothing with trend, naïve method, trend analysis, additive decomposition - CMA, additive decomposition - average all, multiplicative decomposition - CMA, multiplicative decomposition - average All. Kedua, data yang dipakai untuk menghitung/meramalkan adalah jumlah 
tamu yang menginap di hotel mulai periode Januari 2012 sampai Mei 2013, berjumlah 17 data. Ketiga, dari 11 metode forecasting didapat Mean Absolute Deviation (MAD) dan Mean Squared Error (MSE) yang terkecil yaitu MAD 101,69 dan MSE sebesar 15.163,95, dengan metode additive decomposition - average all. Keempat, metode additive decomposition - average all yang menunjukkan bahwa data tersebut memperlihatkan peramalan jumlah tamu yang menginap di Hotel Karlita International untuk periode Juni 2013 sebesar 960,8821 $\approx 960$ tamu. Kelima, penyelesaian dengan menggunakan (peramalan) forecasting dengan 11 metode ini bisa diselesaikan menggunakan perhitungan secara manual dan dengan menggunakan QM (Quantitative Method) for Windows. Baik secara manual maupun dengan program QM for Windows, keduanya menunjukkan hasil yang sama.

\section{DAFTAR PUSTAKA}

Handoko, T. H. (2002). Dasar-dasar Manajemen Produksi dan Operasi. Edisi kesatu. Yogyakarta: BPFE-UGM.

Hanke, J. E., and Wichern, D. W. (2007). Business Forecasting. Eighth Edition. USA: Pearson Prentice Hal.

Heizer, J., Rander, B. (2006). Manajemen Operasi. Judul Asli: Operation Management, diterjemahkan oleh: Dwianoegrahwati dan Indra Almadhy. Buku 1. Edisi ketujuh. Jakarta: Salemba Empat.

Herjanto, E. (2007). Manajemen Operasi. Jakarta: Gramedia Widiasarana.

Ma'arif , S. dan Tanjung, H. (2005). Teknik-teknik Kuantitatif Untuk Manajemen. Jakarta: Gramedia Widiasarana Indonesia.

Makridarkis, S and Wheelwright, S. C. (2006). Metode dan Aplikasi Peramalan. Edisi kedua. Alih bahasa: Untung Sus Andriyanto dan Abdul Basith. Jakarta: Erlangga.

Nasution, Arman Hakim. (2007). Perencanaan dan Pengendalian Produksi. Edisi Kedua Cetakan Kedua. Surabaya: Guna Widya.

Nasution, Arman Hakim; (2006). Manajemen Industri. Yogyakarta: Andi Offset.

Render, B. (2009). Quantitative Analysis for Management. $8^{\text {th }}$ Edition. New Jersey: Prentice Hall.

Render, B., Stair, R. M., and Hanna, M. E. (2006). Quantitative Analysis for Management. International Edition. USA: Pearson Prentice Hall.

Rosida, D. (2006). Pembangunan perangkat lunak peramalan penjualan dan perencanaan pemesanan untuk membantu manajemen persediaan pada perusahaan dagang. Jurnal Teknik Informatika. Bandung: ITB.

Sarjono, H., Agustina, Y., dan Pujadi, A. (2008). Analisis Peramalan Penjualan pada PT Multi Megah Mandiri Tahun 2009. Management Expose. Volume 8 No 17. Jakarta.

Suhermin, A. P. (2002). Peramalan kunjungan wisatawan manca Negara melalui bandara Ngurah Rai dengan analisis Time Serie. Jurnal Statistika, FMIPA. Surabaya: ITS.

Supranto, J. (2005). Matematika Ekonomi dan Bisnis. Jakarta: Salemba Empat.

Tampubolon, M. P. (2004). Manajemen Operasional. Jakarta: Ghalia Indonesia. 